\title{
HYDRODYNAMIC \& WATER QUALITY MODELLING OF SOUTHERN EVOIKOS GULF, GREECE
}

\section{A. I. STAMOU* \\ C. NOUTSOPOULOS \\ K. G. PIPILIS \\ E. GAVALAKI \\ A. ANDREADAKIS}

Received: $16 / 9 / 98$

Accepted: 20/6/99

\author{
Division of Water Resources, Hydraulic and Maritime \\ Engineering, National Technical University of Athens \\ 5, Iroon Polytechniou Street, Zografou 15573 Greece
}

*to whom all correspondence should be addressed

\begin{abstract}
A mathematical model is presented, consisting of a two-layer, finite difference hydrodynamic submodel and a compartmental water quality sub-model. The model is calibrated with field data. Then, it is applied to Southern Evoikos Gulf, an open coastal water body of particular ecological significance in the region of Attiki, in Greece. The application of the model aims at assessing the effect of three alternative treatment scenarios (i.e. biological treatment, biological treatment with $\mathrm{N}$ removal and biological treatment with $\mathrm{N}$ and $\mathrm{P}$ removal) performed in four sewage treatment plants (of a total capacity of $1,000,000$ equivalent population) on the water quality of the Gulf. The calculations show that $\mathrm{N}$ is the limiting nutrient and its removal results in an improvement of the quality of the recipient, whereas the additional implementation of $\mathrm{P}$ removal has a rather limited impact.
\end{abstract}

KEYWORDS: mathematical model, hydrodynamics, water quality, eutrophication, nutrient removal, limiting nutrient, Southern Evoikos Gulf

\section{INTRODUCTION}

Numerical models are useful and cost effective tools in the study of water pollution in coastal areas. Usually, a water pollution model consists of a hydrodynamic sub-model and a water quality sub-model. The hydrodynamic sub-model calculates the flow field by solving the fundamental hydrodynamic equations (Stamou et al, 1995). The water quality sub-model uses the calculated flow velocities as input to determine the concentration fields of the water quality variables of interest by solving the corresponding mass balance equations (Noutsopoulos et al, 1999).

In the present work a model is presented, con- sisting of a two-layer, finite difference hydrodynamic sub-model (HYMOD) and a compartmental water quality sub-model (QUMOD). The model is applied to Southern Evoikos Gulf, an open coastal water body of particular ecological significance located in the eastern side of the Attiki region. In the year 2030 treated sewage will be discharged in the Gulf from 4 Sewage Treatment Plants (STPs) treating sewage from 16 municipalities corresponding to a 1,000,000 equivalent population. The application of the model aims at assessing the effect of 3 alternative treatment scenarios on the water quality of the Gulf. 


\section{THE MODEL}

\subsection{The hydrodynamic model (HYMOD)}

The governing equations of HYMOD are the 3-D, non-steady state continuity and momentum equations expressed in layer formulation (Kowalik and Murty, 1993). Using fixed permeable interfaces between layers, the equations of the model are vertically integrated over a depth range $h$, corresponding to a computational model layer of that thickness. For the distribution of pressure (p), the following assumptions are made: (i) the distribution of $\mathrm{p}$ is hydrostatic, (ii) the Boussinesq approximation is valid and (iii) the pressure at the surface is set equal to the atmospheric (zero).

In the present work HYMOD is applied in its two-layer formulation with $h_{1}$ and $h_{2}$ being the thicknesses of the surface layer (layer 1 ) and the bottom layer (layer 2), respectively, and $\varrho_{1}$ and $\varrho_{2}$ are the densities of the surface and bottom layer, respectively. For a Cartesian coordinate system x, y and $z$, the equations of the model are written as follows:

(1) $x$-momentum equations (for the calculation of velocities $u_{1}$ and $u_{2}$ )

$$
\begin{aligned}
& \frac{\partial \mathrm{u}_{1}}{\partial \mathrm{t}}+\mathrm{u}_{1} \frac{\partial \mathrm{u}_{1}}{\partial \mathrm{x}}+\mathrm{v}_{1} \frac{\partial \mathrm{u}_{1}}{\partial \mathrm{y}}+\mathrm{w}_{1} \frac{\partial \mathrm{u}_{1}}{\partial \mathrm{z}}= \\
& =\mathrm{fv}_{1}-\frac{1}{\rho_{1}} \frac{\partial \mathrm{p}_{1}}{\partial \mathrm{x}}-\mathrm{g} \frac{\partial \zeta}{\partial \mathrm{x}}+\frac{\partial}{\partial \mathrm{x}}\left(\mathrm{v}_{\mathrm{h}} \frac{\partial \mathrm{u}_{1}}{\partial \mathrm{x}}\right)+ \\
& +\frac{\partial}{\partial \mathrm{y}}\left(v_{\mathrm{h}} \frac{\partial \mathrm{u}_{1}}{\partial \mathrm{y}}\right)+\frac{\tau_{\mathrm{sx}}-\tau_{\mathrm{ix}}}{\rho_{1} \cdot \mathrm{h}_{1}} \\
& \frac{\partial \mathrm{u}_{2}}{\partial \mathrm{t}}+\mathrm{u}_{2} \frac{\partial \mathrm{u}_{2}}{\partial \mathrm{x}}+\mathrm{v}_{2} \frac{\partial \mathrm{u}_{2}}{\partial \mathrm{y}}+\mathrm{w}_{2} \frac{\partial \mathrm{u}_{2}}{\partial \mathrm{z}}= \\
& =\mathrm{fv}_{2}-\frac{1}{\rho_{2}} \frac{\partial \mathrm{p}_{2}}{\partial \mathrm{x}}-\mathrm{g} \frac{\partial \zeta}{\partial \mathrm{x}}+\frac{\partial}{\partial \mathrm{x}}\left(v_{\mathrm{h}} \frac{\partial \mathrm{u}_{2}}{\partial \mathrm{x}}\right)+ \\
& +\frac{\partial}{\partial \mathrm{y}}\left(v_{\mathrm{h}} \frac{\partial \mathrm{u}_{2}}{\partial \mathrm{y}}\right)+\frac{\tau_{\mathrm{ix}}-\tau_{\mathrm{bx}}}{\rho_{2} \cdot \mathrm{h}_{2}}
\end{aligned}
$$

(2) y-momentum equations (for the calculation of velocities $v_{1}$ and $v_{2}$ )

$$
\begin{aligned}
& \frac{\partial \mathrm{v}_{1}}{\partial \mathrm{t}}+\mathrm{u}_{1} \frac{\partial \mathrm{v}_{1}}{\partial \mathrm{x}}+\mathrm{v}_{1} \frac{\partial \mathrm{v}_{1}}{\partial \mathrm{y}}+\mathrm{w}_{1} \frac{\partial \mathrm{v}_{1}}{\partial \mathrm{z}}= \\
& =-\mathrm{fu}_{1}-\frac{1}{\rho_{1}} \frac{\partial \mathrm{p}_{1}}{\partial \mathrm{y}}-\mathrm{g} \frac{\partial \zeta}{\partial \mathrm{y}}+ \\
& +\frac{\partial}{\partial \mathrm{x}}\left(\mathrm{v}_{\mathrm{h}} \frac{\partial \mathrm{v}_{1}}{\partial \mathrm{x}}\right)+\frac{\partial}{\partial \mathrm{y}}\left(\mathrm{v}_{\mathrm{h}} \frac{\partial \mathrm{v}_{1}}{\partial \mathrm{y}}\right)+\frac{\tau_{\mathrm{sy}}-\tau_{\mathrm{iy}}}{\rho_{1} \cdot \mathrm{h}_{1}}
\end{aligned}
$$

$$
\begin{aligned}
& \frac{\partial \mathrm{v}_{2}}{\partial \mathrm{t}}+\mathrm{u}_{2} \frac{\partial \mathrm{v}_{2}}{\partial \mathrm{x}}+\mathrm{v}_{2} \frac{\partial \mathrm{v}_{2}}{\partial \mathrm{y}}+\mathrm{w}_{2} \frac{\partial \mathrm{v}_{2}}{\partial \mathrm{z}}= \\
& =-\mathrm{fu}_{2}-\frac{1}{\rho_{2}} \frac{\partial \mathrm{p}_{2}}{\partial \mathrm{y}}-\mathrm{g} \frac{\partial \zeta}{\partial \mathrm{y}}+ \\
& +\frac{\partial}{\partial \mathrm{x}}\left(v_{\mathrm{h}} \frac{\partial \mathrm{v}_{2}}{\partial \mathrm{x}}\right)+\frac{\partial}{\partial \mathrm{y}}\left(v_{\mathrm{h}} \frac{\partial \mathrm{v}_{2}}{\partial \mathrm{y}}\right)+\frac{\tau_{\mathrm{iy}}-\tau_{\mathrm{sy}}}{\rho_{2} \cdot \mathrm{h}_{2}}
\end{aligned}
$$

In equations (1) - (4) $\mathrm{u}_{1}, \mathrm{v}_{1}$ and $\mathrm{w}_{1}$ are the layer averaged velocity components for the surface layer and $\mathrm{u}_{2}, \mathrm{v}_{2}$ and $\mathrm{w}_{2}$ for the bottom layer, respectively (along the axes $\mathrm{x}, \mathrm{y}$ and $\mathrm{z}$, respectively), $\zeta$ is the free surface elevation, $t$ is the time, $v_{h}$ is the horizontal eddy viscosity coefficient, $\mathrm{f}$ is the Coriolis parameter and $g$ is the gravitational acceleration.

(3) z-momentum equations (for the calculation of the pressure)

The z-momentum equations are simplified to the hydrostatic $\mathrm{p}$-distribution equations, from which the pressure terms (i.e. these involving $\mathrm{p}_{1}$ and $\mathrm{p}_{2}$ ) in the equations (1) - (4) can be determined.

\section{(3) Shear stresses equations}

For the calculation of the horizontal components of the vertical shear for the boundaries along the $z$-axis, i.e. at the bottom ( $\tau_{b x}$ and $\left.\tau_{b y}\right)$, at the interface $\left(\tau_{\text {ix }}\right.$ and $\left.\tau_{\text {iy }}\right)$ and at the surface $\left(\tau_{\mathrm{sx}}\right.$ and $\left.\tau_{\text {sy }}\right)$ the following equations are used:

$$
\begin{aligned}
& \frac{\tau_{\mathrm{bx}}}{\rho_{2}}=\mathrm{C}_{\mathrm{b}} \mathrm{u}_{2} \sqrt{\mathrm{u}_{2}^{2}+\mathrm{v}_{2}^{2}} \\
& \frac{\tau_{\mathrm{by}}}{\rho_{2}}=\mathrm{C}_{\mathrm{b}} \mathrm{v}_{2} \sqrt{\mathrm{u}_{2}^{2}+\mathrm{v}_{2}^{2}} \\
& \frac{\tau_{\mathrm{sx}}}{\rho_{1}}=\mathrm{C}_{\mathrm{s}} \mathrm{u}_{10} \sqrt{\mathrm{u}_{10}^{2}+\mathrm{v}_{10}^{2}}
\end{aligned}
$$

and

$$
\frac{\tau_{\mathrm{sy}}}{\mathrm{\varrho}_{1}}=\mathrm{C}_{\mathrm{s}} \mathrm{v}_{10} \sqrt{\mathrm{u}_{10}^{2}+\mathrm{v}_{10}^{2}}
$$

$\frac{\tau_{\mathrm{ix}}}{\rho_{1}}=\mathrm{C}_{\mathrm{i}}\left(\mathrm{u}_{1}-\mathrm{u}_{2}\right) \sqrt{\left(\mathrm{u}_{1}-\mathrm{u}_{2}\right)^{2}+\left(\mathrm{v}_{1}-\mathrm{v}_{2}\right)^{2}}$ and

$$
\frac{\tau_{\mathrm{ix}}}{\rho_{2}}=\mathrm{C}_{\mathrm{i}}\left(\mathrm{u}_{2}-\mathrm{u}_{1}\right) \sqrt{\left(\mathrm{u}_{1}-\mathrm{u}_{2}\right)^{2}+\left(\mathrm{v}_{1}-\mathrm{v}_{2}\right)^{2}}
$$




$$
\begin{aligned}
& \frac{\tau_{\text {iy }}}{\rho_{1}}=C_{i}\left(v_{1}-v_{2}\right) \sqrt{\left(u_{1}-u_{2}\right)^{2}+\left(v_{1}-v_{2}\right)^{2}} \text { and } \\
& \frac{\tau_{\text {iy }}}{\rho_{2}}=C_{i}\left(v_{2}-v_{1}\right) \sqrt{\left(u_{1}-u_{2}\right)^{2}+\left(v_{1}-v_{2}\right)^{2}}
\end{aligned}
$$

where $\mathrm{u}_{10}$ and $\mathrm{v}_{10}$ are the wind velocity components at a $10 \mathrm{~m}$ height from the surface along axes $\mathrm{x}$ and $\mathrm{y}$, respectively, and $\mathrm{C}_{\mathrm{b}}, \mathrm{C}_{\mathrm{i}}$ and $\mathrm{C}_{\mathrm{s}}$ are the shear stress coefficients at the bottom, at the interface and at the surface, respectively.

(4) Continuity equations (for the calculation of vertical velocities and the surface elevation)

Horizontal velocities $\mathrm{u}_{1}, \mathrm{v}_{1}, \mathrm{u}_{2}$ and $\mathrm{v}_{2}$ are calculated by solving the $\mathrm{x}$ - and $\mathrm{y}$-momentum equations (1) - (4). The layered averaged velocities $\mathrm{w}_{1}$ and $\mathrm{w}_{2}$, appearing in the $\mathrm{x}$-and $\mathrm{y}$-momentum equations, are exressed as functions of the vertical velocities (a) at the interface of the two layers, $w_{i}$, (b) at the bottom, $\mathrm{w}_{\mathrm{b}}$, and (c) at the surface, $\mathrm{w}_{\mathrm{s}}$. At the sea bottom, the kinematic boundary condition $\mathrm{w}_{\mathrm{b}}=0$ is used. The velocities $\mathrm{w}_{\mathrm{i}}$ and $\mathrm{w}_{\mathrm{s}}$ and the surface elevation $(\zeta)$ are calculated by the following integrated continuity equations for the two layers.

$$
\begin{aligned}
\mathrm{w}_{\mathrm{i}} & =-\left[\frac{\partial}{\partial \mathrm{x}}\left(\mathrm{u}_{2} \cdot \mathrm{h}_{2}\right)+\frac{\partial}{\partial \mathrm{y}}\left(\mathrm{v}_{2} \cdot \mathrm{h}_{2}\right)\right] \\
\mathrm{w}_{\mathrm{s}} & =\frac{\partial \zeta}{\partial \mathrm{t}}= \\
& =\mathrm{w}_{\mathrm{i}}-\left[\frac{\partial}{\partial \mathrm{x}}\left(\mathrm{u}_{1} \cdot \mathrm{h}_{1}\right)+\frac{\partial}{\partial \mathrm{y}}\left(\mathrm{v}_{1} \cdot \mathrm{h}_{1}\right)\right]
\end{aligned}
$$

\subsection{The water quality model (QUMOD)}

The equations of QUMOD, which are derived by applying the mass conservation principle to a finite completely mixed control volume (or cell) within the flow, are written as follows:

$$
\begin{aligned}
& \frac{\partial \mathrm{u}_{1}}{\partial \mathrm{t}}+\mathrm{u}_{1} \frac{\partial \Phi_{\mathrm{k} 1}}{\partial \mathrm{x}}+\mathrm{v}_{1} \frac{\partial \Phi_{\mathrm{k} 1}}{\partial \mathrm{y}}= \\
& =\frac{\partial}{\partial \mathrm{x}}\left(\mathrm{E} \frac{\partial \Phi_{\mathrm{k} 1}}{\partial \mathrm{x}}\right)+ \\
& +\frac{\partial}{\partial \mathrm{y}}\left(\mathrm{E} \frac{\partial \Phi_{\mathrm{k} 1}}{\partial \mathrm{y}}\right)+\mathrm{r}_{\Phi \mathrm{k} 1}+\mathrm{w}_{\Phi \mathrm{k} 2} \\
& \frac{\partial \mathrm{u}_{2}}{\partial \mathrm{t}}+\mathrm{u}_{2} \frac{\partial \Phi_{\mathrm{k} 2}}{\partial \mathrm{x}}+\mathrm{v}_{2} \frac{\partial \Phi_{\mathrm{k} 2}}{\partial \mathrm{y}}= \\
& =\frac{\partial}{\partial \mathrm{x}}\left(\mathrm{E} \frac{\partial \Phi_{\mathrm{k} 2}}{\partial \mathrm{x}}\right)+ \\
& =\frac{\partial}{\partial \mathrm{y}}\left(\mathrm{E} \frac{\partial \Phi_{\mathrm{k} 2}}{\partial \mathrm{y}}\right)+\mathrm{r}_{\Phi \mathrm{k} 1}+\mathrm{w}_{\Phi \mathrm{k} 2}
\end{aligned}
$$

where $\Phi_{\mathrm{k} 1}$ and $\Phi_{\mathrm{k} 2}$ are the mean concentrations of each water quality variable $\Phi\left(\mathrm{g} \mathrm{m}^{-3}\right), \mathrm{r}_{\Phi \mathrm{k} 1}$ and $\mathrm{r}_{\Phi \mathrm{k} 2}$ are the reaction terms $\left(\right.$ day-1 $\left.^{-1} \mathrm{mg} \mathrm{l}^{-1}\right), \mathrm{w}_{\Phi \mathrm{k} 1}$ and $\mathrm{w}_{\Phi \mathrm{k} 2}$ are the external loads ( day $^{-1} \mathrm{mg} \mathrm{l}^{-1}$ ) at the surface and bottom layers, respectively and $\mathrm{E}$ is the dispersion coefficient $\left(\mathrm{m}^{2}\right.$ day $\left.{ }^{-1}\right)$. The following

\begin{tabular}{|c|c|c|c|c|c|c|c|c|}
\hline $\mathrm{R}_{\Phi \mathrm{k}}$ & $\begin{array}{l}\text { Growth of A } \\
\text { Photosynthesis }\end{array}$ & Decay of A & $\begin{array}{l}\text { Respiration } \\
\text { of A }\end{array}$ & $\begin{array}{l}\text { Nitrification- } \\
\text { Oxidation } \\
\end{array}$ & Settling & OP to IP & Reaeration & $\begin{array}{l}\text { Benthic DO } \\
\text { Demand }\end{array}$ \\
\hline $\mathrm{R}_{\mathrm{Ak}}$ & $+\mu_{\mathrm{A}} \mathrm{A}_{\mathrm{k}}$ & $-\mathrm{K}_{\mathrm{dA}} \mathrm{A}_{\mathrm{k}}$ & $-\mathrm{R}_{\mathrm{A}} \mathrm{A}_{\mathrm{k}}$ & & $-\mathrm{K}_{\mathrm{SA}} \mathrm{A}_{\mathrm{k}}$ & & & \\
\hline $\mathrm{R}_{\mathrm{OPk}}$ & & $+\mathrm{K}_{\mathrm{dA}} \mathrm{A}_{\mathrm{k}} \mathrm{Y} 1$ & $+\mathrm{R}_{\mathrm{A}} \mathrm{A}_{\mathrm{k}} \mathrm{Y}_{1}$ & & $-\mathrm{K}_{\mathrm{SP}} \mathrm{OP}_{\mathrm{k}}$ & $-\mathrm{R}_{\mathrm{P}} \mathrm{OP}_{\mathrm{k}}$ & & \\
\hline $\mathrm{R}_{\mathrm{IPk}}$ & $-\mu_{\mathrm{A}} \mathrm{A}_{\mathrm{k}} \mathrm{Y}_{1}$ & & & & & $+\mathrm{R}_{\mathrm{p}} \mathrm{OP}_{\mathrm{k}}$ & & \\
\hline $\mathrm{R}_{\mathrm{NHk}}$ & $-\mu_{\mathrm{A}} \mathrm{A}_{\mathrm{k}} \mathrm{Y}_{2} \mathrm{P}_{\mathrm{NH}}$ & $+\mathrm{K}_{\mathrm{dA}} \mathrm{A}_{\mathrm{k}} \mathrm{Y}_{2}$ & & $-\mathrm{R}_{\mathrm{N}} \mathrm{NH}_{\mathrm{k}}$ & & & & \\
\hline $\mathrm{R}_{\mathrm{Nok}}$ & $-\mu_{\mathrm{A}} \mathrm{A}_{\mathrm{k}} \mathrm{Y}_{2}$ & & & $+\mathrm{R}_{\mathrm{N}} \mathrm{NH}_{\mathrm{k}}$ & & & & \\
\hline & $\left(1-\mathrm{P}_{\mathrm{NH}}\right)$ & & & & & & & \\
\hline $\mathrm{R}_{\mathrm{Ck}}$ & & $+\mathrm{K}_{\mathrm{dA}} \mathrm{A}_{\mathrm{k}} \mathrm{Y}_{3}$ & & $-\mathrm{R}_{\mathrm{L}} \mathrm{C}_{\mathrm{k}}$ & $-\mathrm{K}_{\mathrm{SA}} \mathrm{C}_{\mathrm{k}}$ & & & \\
\hline $\mathrm{R}_{\mathrm{DOk}}$ & $+\mathrm{Y}_{4} \mathrm{~A}_{\mathrm{k}} \mathrm{u}_{\max } \mathrm{f}^{\prime}$ & & $-\mathrm{R}_{\mathrm{A}} \mathrm{A}_{\mathrm{k}} \mathrm{Y}_{3}$ & $\begin{array}{l}-\mathrm{R}_{\mathrm{L}} \mathrm{C}_{\mathrm{k}} \\
-4.5 \mathrm{R}_{\mathrm{N}} \mathrm{NH}_{\mathrm{k}}\end{array}$ & & & $\begin{array}{l}+\mathrm{k}\left(\mathrm{C}_{\mathrm{S}^{-}}\right. \\
\left.\mathrm{DO}_{\mathrm{k}}\right) / \mathrm{H}_{\mathrm{k}}\end{array}$ & -SODk/Hk \\
\hline
\end{tabular}
water quality variables are considered in QUMOD: chlorophyll-a $(\Phi=\mathrm{A})$, organic phosphorus $(\Phi=\mathrm{OP})$, inorganic phosphorus $(\Phi=\mathrm{IP})$, ammoniacal nitrogen $(\Phi=\mathrm{NH})$, oxidized nitrogen $(\Phi=\mathrm{NO})$, BOD $(\Phi=\mathrm{C})$, dissolved oxygen $(\Phi=\mathrm{DO})$ and transparency in terms of Secchi Disks $(\Phi=\mathrm{SD})$. The reaction term, which represents the sum of all conversion rates for each water quality variable is shown in Table 3. The

Table 3. The reaction terms of the variables of the water quality model 
Table 4. The kinetic and stoichiometric parameters of the water quality model

\begin{tabular}{|c|c|c|}
\hline Parameter [units] & Description - Coefficient & Value or equation \\
\hline $\mathrm{B}[\mathrm{m}]$ & Resuspension coefficient & 12.50 \\
\hline $\mathrm{f}$ & & $\begin{array}{l}2.718 \mathrm{~F} / \mathrm{KH}_{\mathrm{k}} \\
\left\{\exp \left[\left(-\mathrm{I}_{\mathrm{O}} / \mathrm{I}_{\mathrm{S}}\right) \exp \left(-\mathrm{KH}_{\mathrm{k}}\right)\right]-\exp \left(-\mathrm{I}_{\mathrm{O}} / \mathrm{I}_{\mathrm{S}}\right)\right\}\end{array}$ \\
\hline $\mathrm{F}[-]$ & Photoperiod & $0.32+0.20[1-\cos (\mathrm{t}-15) 360 / 365]$ \\
\hline $\mathrm{H}_{\mathrm{k}}[\mathrm{m}]$ & Mean depth of segment $\mathrm{k}$ & - \\
\hline $\mathrm{I}_{\mathrm{o}}\left[\mathrm{cal} \mathrm{cm}^{-2}\right.$ day $\left.^{-1}\right]$ & Incident radiation & $120+192[1-\cos (\mathrm{t}-15) 360 / 365]$ \\
\hline $\mathrm{I}_{\mathrm{s}}\left[\mathrm{cal} \mathrm{cm}^{-2}\right.$ day-1 $\left.^{-1}\right]$ & Critical sunlight intensity & 300 \\
\hline $\mathrm{K}\left[\mathrm{m}^{-1}\right]$ & Light extiction coefficient & \\
\hline $\mathrm{K}_{\mathrm{dA}}\left[\right.$ day $\left.^{-1}\right]$ & Death rate coefficient for $A_{k}$ at $T^{\circ} \mathrm{C}$ & $\mathrm{K}_{\mathrm{dA} 20} 1.120^{(\mathrm{T}-20)}$ \\
\hline $\mathrm{K}_{\mathrm{dA20}}\left[\mathrm{day}^{-1}\right]$ & $\mathrm{K}_{\mathrm{dA}}$ at $20^{\circ} \mathrm{C}$ & 0.10 \\
\hline $\mathrm{K}_{\mathrm{N}}\left[\mathrm{mg} \mathrm{l}^{-1}\right]$ & Monod kinetic constant for $\mathrm{NO}_{\mathrm{k}}$ or $\mathrm{NH}_{\mathrm{k}}$ & $\mathrm{K}_{\mathrm{N} 0} 1.0415 \mathrm{~T}$ \\
\hline $\mathrm{K}_{\mathrm{N} 0}\left[\mathrm{mg} \mathrm{l}^{-1}\right]$ & $\mathrm{K}_{\mathrm{N}}$ at $0^{\circ} \mathrm{C}$ & 0.005 \\
\hline $\mathrm{K}_{\mathrm{P}}\left[\mathrm{mg} \mathrm{l}^{-1}\right]$ & Monod kinetic constant for $\mathrm{OP}_{\mathrm{k}}$ or $\mathrm{IP}_{\mathrm{k}}$ & 0.0001 \\
\hline $\mathrm{K}_{\mathrm{SA}}\left[\right.$ day $\left.^{-1}\right]$ & Settling velocity coefficient for $A_{k}$ & $\mathrm{~V}_{\mathrm{Amax}} /\left(\mathrm{H}_{\mathrm{k}}+\mathrm{B}\right)$ \\
\hline $\mathrm{K}_{\mathrm{SP}}\left[\right.$ day $\left.^{-1}\right]$ & Settling velocity coefficient for $\mathrm{OP}_{\mathrm{k}}$ & $\mathrm{V}_{\mathrm{Pmax}} /\left(\mathrm{H}_{\mathrm{k}}+\mathrm{B}\right)$ \\
\hline$\mu_{\mathrm{A}}\left[\right.$ day $\left.^{-1}\right]$ & Phytoplankton growth rate & $\begin{array}{c}\mu_{\max } 1.06(\mathrm{~T}-20) \mathrm{f} \\
\left\{\left(\mathrm{NO}_{\mathrm{k}}+\mathrm{NH}_{\mathrm{k}}\right) /\left(\mathrm{NO}_{\mathrm{k}}+\mathrm{NH}_{\mathrm{k}}+\mathrm{K}_{\mathrm{N}}\right)\right\} \\
\left\{\left(\mathrm{IP}_{\mathrm{k}}+\mathrm{OP}_{\mathrm{k}}\right) /\left(\mathrm{IP}_{\mathrm{k}}+\mathrm{OP}_{\mathrm{k}}+\mathrm{K}_{\mathrm{P}}\right)\right\}\end{array}$ \\
\hline$\mu_{\max }\left[\right.$ day $\left.^{-1}\right]$ & Maximum $\mu_{\mathrm{A}}$ & 2.50 \\
\hline $\mathrm{P}_{\mathrm{NH}}[-]$ & Preference coefficient & $0.96 \mathrm{NH}_{\mathrm{k}} /\left(0.96 \mathrm{NH}_{\mathrm{k}}+0.04 \mathrm{NO}_{\mathrm{k}}\right)$ \\
\hline $\mathrm{R}_{\mathrm{A}}\left[\right.$ day $\left.^{-1}\right]$ & Endogenous respiration coef. at $\mathrm{T}^{\circ} \mathrm{C}$ & $\mathrm{R}_{\mathrm{A} 0}+0.00420 \mathrm{~T}$ \\
\hline $\mathrm{R}_{\mathrm{A} 0}\left[\right.$ day $\left.^{-1}\right]$ & $\mathrm{R}_{\mathrm{A}}$ at $0^{\circ} \mathrm{C}$ & 0.0 \\
\hline $\mathrm{R}_{\mathrm{RE}}\left[\right.$ day $\left.^{-1}\right]$ & Reaeration coefficient & 1.0 \\
\hline $\mathrm{R}_{\mathrm{N}}\left[\right.$ day $\left.^{-1}\right]$ & Nitrification rate coefficient at $\mathrm{T}^{\circ} \mathrm{C}$ & $\mathrm{R}_{\mathrm{N} 20} 1.166^{\mathrm{T}-20}$ \\
\hline $\mathrm{R}_{\mathrm{N} 20}\left[\right.$ day $\left.^{-1}\right]$ & $\mathrm{R}_{\mathrm{N}}$ at $20^{\circ} \mathrm{C}$ & 0.020 \\
\hline $\mathrm{R}_{\mathrm{L}}\left[\right.$ day $\left.^{-1}\right]$ & BOD decay coefficient at $\mathrm{T}^{\circ} \mathrm{C}$ & $\mathrm{R}_{\mathrm{L} 20} 1.040 \mathrm{~T}-20$ \\
\hline $\mathrm{R}_{\mathrm{L} 20}\left[\right.$ day $\left.^{-1}\right]$ & $\mathrm{R}_{\mathrm{L}}$ at $20^{\circ} \mathrm{C}$ & 0.20 \\
\hline $\mathrm{R}_{\mathrm{P}}$ & Conversion coef. of $\mathrm{OP}_{\mathrm{k}}$ to $\mathrm{IP}_{\mathrm{k}}$ & $\mathrm{R}_{\mathrm{P} 0}+0.005 \mathrm{~T}$ \\
\hline $\mathrm{R}_{\mathrm{P} 0}\left[\right.$ day $\left.^{-1}\right]$ & $\mathrm{R}_{\mathrm{P}}$ at $0{ }^{\circ} \mathrm{C}$ & 0.400 \\
\hline $\mathrm{SOD}\left[\mathrm{grO}_{2}\right.$ day $\left.^{-1} \mathrm{~m}^{-2}\right]$ & Sediment Oxygen Demand & $0.15-0.40$ \\
\hline $\mathrm{T}$ [days] & Time ( $\mathrm{t}=0$ at the the $1^{\text {st }}$ of December) & \\
\hline $\mathrm{T}\left[{ }^{\circ} \mathrm{C}\right]$ & Temperature of the homogenous layer & $13+6[1-\cos (\mathrm{t}-76) 360 / 365]$ \\
\hline $\mathrm{T}_{\mathrm{S}}\left[{ }^{\circ} \mathrm{C}\right]$ & Temperature of the surface layer & $13+6[1-\cos (\mathrm{t}-76) 360 / 365]$ \\
\hline $\mathrm{T}_{\mathrm{b}}\left[{ }^{\circ} \mathrm{C}\right]$ & Temperature of the bottom layer & $13+3[1-\cos (\mathrm{t}-76) 360 / 365]$ \\
\hline $\mathrm{Y}_{1}[\mathrm{mgP} / \mathrm{mgChl}]$ & $\mathrm{P}$ content of $\mathrm{A}$ & 0.80 \\
\hline $\mathrm{Y}_{2}[\mathrm{mgN} / \mathrm{mgChl}]$ & $\mathrm{N}$ content of $\mathrm{A}$ & 11.00 \\
\hline $\mathrm{Y}_{3}[\mathrm{mgBOD} / \mathrm{mgChl}]$. & BOD content of A & 50 \\
\hline $\mathrm{Y}_{4}[\mathrm{mgO} / \mathrm{mgChl}]$. & DO content of $\mathrm{A}$ & 50 \\
\hline $\mathrm{V}_{\text {Amax }}\left[\mathrm{m}\right.$ day $\left.^{-1}\right]$ & Max. settling velocity for $A_{k}$ & 0.10 \\
\hline $\mathrm{V}_{\mathrm{Pmax}}\left[\mathrm{m} \mathrm{day}^{-1}\right]$ & Max. settling velocity for $\mathrm{OP}_{k}$ & 0.085 \\
\hline
\end{tabular}

expressions and the values of the kinetic and stoichiometric parameters are shown in Table 4. The assumptions of the model can be easily deduced from the equations of Tables 3 and 4 . More information on the model can be found in Noutsopoulos et al (1999).
3. APPLICATION OF THE MODEL - RESULTS AND DISCUSSION

3.1 The area and the purpose of the study Approximations - Boundary conditions

The model is applied to Southern Evoikos Gulf, an open coastal water body located in 
Table 5. Pollution Loads

\begin{tabular}{|c|c|c|c|c|c|c|}
\hline \multirow[t]{2}{*}{$\begin{array}{l}\text { Loads } \\
\text { (kg/day) }\end{array}$} & \multicolumn{2}{|c|}{$\begin{array}{c}\text { Scenario } 1 \\
\text { Biological treatment }\end{array}$} & \multicolumn{2}{|c|}{$\begin{array}{c}\text { Scenario } 2 \\
\text { Biological treatment } \\
\text { \& N removal } \\
\end{array}$} & \multicolumn{2}{|c|}{$\begin{array}{c}\text { Scenario } 3 \\
\text { Biological treatment } \\
\text { \& N and P removal }\end{array}$} \\
\hline & Winter & Summer & Winter & Summer & Winter & Summer \\
\hline \multicolumn{7}{|l|}{ Kynosoura } \\
\hline BOD & 550 & 1120 & 550 & 1120 & 550 & 1120 \\
\hline $\mathrm{N}$ & 270 & 540 & 220 & 450 & 220 & 450 \\
\hline $\mathrm{P}$ & 205 & 405 & 205 & 405 & 39 & 83,5 \\
\hline \multicolumn{7}{|l|}{$\underline{\text { Velani }}$} \\
\hline$\overline{\mathrm{BOD}}$ & 1674 & 2140 & 1674 & 2140 & 1674 & 2140 \\
\hline $\mathrm{N}$ & 1930 & 3160 & 836 & 1070 & 836 & 1070 \\
\hline $\mathrm{P}$ & 502 & 805 & 502 & 805 & 84 & 105 \\
\hline \multicolumn{7}{|l|}{ Chamolia } \\
\hline $\mathrm{BOD}$ & 1175 & 1255 & 1175 & 1255 & 1175 & 1255 \\
\hline $\mathrm{N}$ & 1210 & 1595 & 550 & 595 & 550 & 595 \\
\hline $\mathrm{P}$ & 400 & 500 & 400 & 500 & 67 & 71 \\
\hline \multicolumn{7}{|l|}{ Vrisaki } \\
\hline BOD & 260 & 540 & 260 & 540 & 260 & 540 \\
\hline $\mathrm{N}$ & 370 & 950 & 158 & 275 & 158 & 275 \\
\hline $\mathrm{P}$ & 105 & 261 & 105 & 261 & 19 & 31 \\
\hline
\end{tabular}

Central Greece, in the eastern coast of Attiki. In Fig. 1 the area of study is shown, as approximated by QUMOD. The Water Authority of the Greater Area of Athens (EYDAP) is planning to construct 4 STPs in the coastal area of eastern Attica, which will be discharging to the Gulf treated sewage from 16 municipalities corresponding to an equivalent population of $1,000,000$. The STPs, noted by arrows in Fig.1, will be constructed at the following locations (see Fig.1): (1) Kynosoura cape, (2) Velani cape, (3) Chamolia and (4) Vrisaki cape.

The application of the model aims at assessing the effect of 3 alternative treatment scenarios performed in the 4 STPs on the water quality (mainly the eutrophication status) of the Gulf. The 3 scenarios are: (1) Biological treatment, (2) Biological treatment with $\mathrm{N}$ removal (nitrification-denitrification) and (3) Biological treatment with $\mathrm{N}$ and $\mathrm{P}$ removal. The corresponding pollution loads for the 3 alternative treatment scenarios are shown in Table 5.

Numerical grid and boundary conditions of HYMOD. Southern Evoikos Gulf has a surface of roughly $2,400 \mathrm{~km}^{2}$. The bathymetry shows an increase of depth from the north to the south and from the west to the east, with depths ranging from 10 to $160 \mathrm{~m}$. In Fig. 2 the area of study is shown, as approximated by the computational grid of HYMOD. A space staggered quadrangular grid consisting of $16 \times 29$ points with a $2500 \mathrm{~m}$ resolution is used. This relatively coarse grid has been selected, after performing a grid independence test.

The computational area is surrounded by solid and open sea boundaries. The solid boundaries are parts of the western coast of Attiki (eastern boundary) and of the islands of Evoia and Kavaliani (northern and eastern boundaries), Kea (eastern and southern boundaries) and Makronisos (southern). There are four open sea boundaries. In the northern boundary there is a narrow opening (Agia Marina-Nisos Kavaliani), which connects Southern with Northern Evoikos Gulf. In the eastern boundary, there is a wide opening between Cape Paximadi (of the island of Evoia) and the island of Kea. Finally, there are two openings to the south; a wide one between the islands of Kea and Makronisos and a short one between the island of Makronisos and the coast of Attiki (Cape Sounion).

On the basis of a series of field studies performed by the National Center for Marine Research (NCMR, 1997) and other existing studies and observations, coastal circulation in the area is generated by the winds (mainly along the coast of eastern Attiki) and by the action of the 


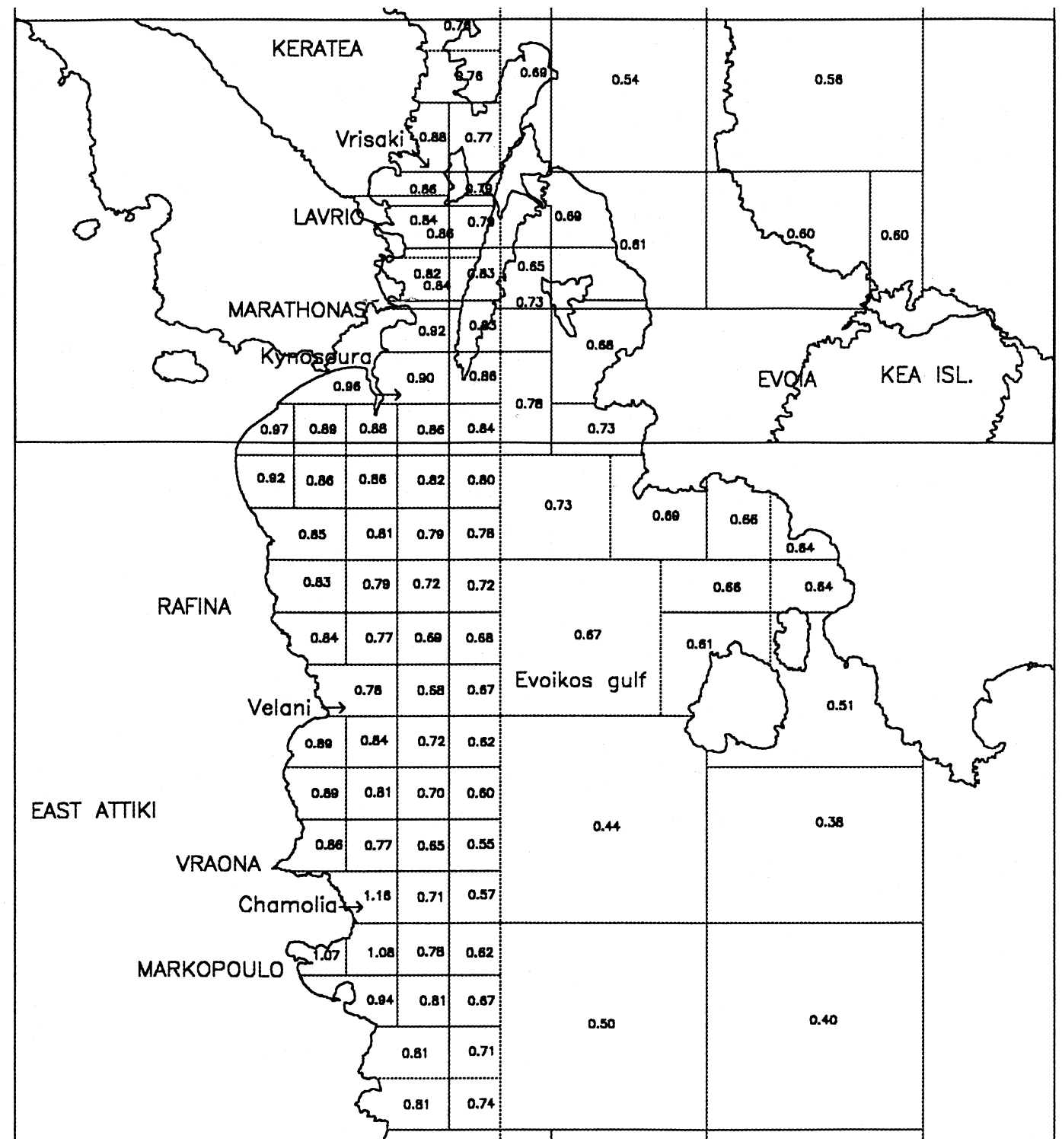

Figure 1. Area of study as modeled by QUMOD

(Figures represent Chlorophyll-a concentrantions at the surface layer for scenario 2, see Table 8) 


\begin{tabular}{|c|c|c|c|c|c|c|c|c|c|c|c|c|c|c|c|}
\hline 0 & 67 & 71 & 70 & 68 & 0 & 0 & 0 & 0 & 0 & 0 & 0 & 0 & 0 & 0 & 0 \\
\hline 0 & 67 & 71 & 70 & 68 & 0 & 0 & 0 & 0 & 0 & 0 & 0 & 0 & 0 & 0 & 0 \\
\hline 0 & 0 & 67 & 64 & 60 & 0 & 0 & 0 & 0 & 0 & 0 & 0 & 0 & 0 & 0 & 0 \\
\hline 0 & 0 & AM & 65 & 62 & Ka & 0 & 0 & 0 & 0 & 0 & 0 & 0 & 0 & 0 & 0 \\
\hline 0 & 0 & 0 & 0 & 50 & 60 & 55 & 60 & 0 & 0 & 0 & 0 & 0 & 0 & 0 & 0 \\
\hline 0 & 0 & 0 & 0 & 20 & 40 & 58 & St & 0 & 0 & 0 & 0 & $\mathbf{E}$ & 0 & 0 & 0 \\
\hline 0 & $\mathbf{M}$ & 0 & 0 & 42 & 55 & 65 & 50 & 0 & 0 & 0 & 0 & 0 & 0 & 0 & 0 \\
\hline 0 & 0 & 15 & Ky & 50 & 60 & 66 & 55 & 0 & 0 & 0 & 0 & 0 & 0 & 0 & 0 \\
\hline 0 & 10 & 25 & 36 & 40 & 55 & 62 & 61 & 60 & 0 & 0 & 0 & 0 & 0 & 0 & 0 \\
\hline 0 & 13 & 26 & 33 & 36 & 50 & 53 & 62 & 65 & 40 & 45 & 0 & 0 & 0 & 0 & 0 \\
\hline 0 & 0 & 30 & 34 & 36 & 40 & 45 & 60 & 70 & 80 & 70 & 40 & 0 & 0 & 0 & 0 \\
\hline 0 & 0 & 28 & 43 & 50 & 60 & 60 & 65 & 70 & 68 & 35 & 25 & 0 & 0 & 0 & 0 \\
\hline 0 & $\mathbf{R}$ & 33 & 50 & 60 & 70 & 75 & 75 & 65 & 58 & $\mathbf{P}$ & 0 & 0 & 0 & 0 & 0 \\
\hline 0 & 0 & $\mathbf{V e}$ & 52 & 68 & 75 & 78 & 80 & 68 & 50 & 0 & 0 & 66 & 0 & 0 & 0 \\
\hline 0 & 0 & 25 & 55 & 78 & 80 & 85 & 82 & 77 & 70 & 75 & 85 & 78 & 45 & 0 & $\mathbf{P B}$ \\
\hline 0 & 0 & 35 & 60 & 75 & 85 & 90 & 90 & 95 & 98 & 99 & 98 & 97 & 80 & 75 & 75 \\
\hline 0 & 0 & 25 & 55 & 78 & 95 & 100 & 110 & 103 & 110 & 105 & 104 & 112 & 105 & 100 & 100 \\
\hline 0 & 0 & $\mathbf{C h}$ & 65 & 87 & 98 & 120 & 130 & 132 & 125 & 120 & 121 & 118 & 120 & 108 & 108 \\
\hline 0 & $\mathbf{P R}$ & 12 & 64 & 100 & 105 & 122 & 132 & 134 & 136 & 140 & 130 & 125 & 120 & 115 & 115 \\
\hline 0 & 0 & 0 & 46 & 100 & 107 & 128 & 130 & 132 & 137 & 150 & 140 & 135 & 130 & 120 & 120 \\
\hline 0 & 0 & 0 & 0 & 90 & 110 & 125 & 127 & 133 & 140 & 160 & 155 & 141 & 132 & 122 & 122 \\
\hline 0 & 0 & 0 & 0 & 80 & 115 & 130 & 132 & 134 & 139 & 150 & 148 & 140 & 135 & 126 & 126 \\
\hline 0 & 0 & 0 & 0 & 0 & 108 & 135 & 137 & 135 & 138 & 140 & 144 & 130 & 125 & 120 & 120 \\
\hline 0 & 0 & 0 & 0 & $\mathbf{V r}$ & 95 & 105 & 115 & 130 & 135 & 138 & 140 & 125 & 118 & 119 & 119 \\
\hline 0 & 0 & 0 & 0 & 50 & 70 & 0 & 95 & 120 & 125 & 130 & 120 & 117 & 115 & 118 & 118 \\
\hline 0 & 0 & 0 & $\mathrm{~L}$ & 48 & 42 & 0 & 105 & 115 & 122 & 123 & 110 & 120 & 110 & 110 & 110 \\
\hline 0 & 0 & 0 & 0 & 35 & $\mathbf{M a}$ & 80 & 118 & 120 & 121 & 110 & 100 & 110 & 105 & 103 & 103 \\
\hline 0 & 0 & 0 & 0 & 30 & 0 & 90 & 120 & 110 & 105 & 100 & 95 & 75 & $\mathbf{K}$ & 0 & 0 \\
\hline 0 & 0 & 0 & $\mathbf{S}$ & 30 & 0 & 90 & 120 & 110 & 105 & 100 & 95 & 75 & 0 & 0 & 0 \\
\hline
\end{tabular}

$\mathrm{AM}=$ Agia Marina, $\mathrm{M}=$ Marathonas, $\mathrm{R}=$ Raphina, $\mathrm{PR}=$ Porto-Rafti, $\mathrm{L}=$ Lavrio, $\mathrm{S}=$ Sounio, $\mathrm{Ma}=$ Makronisos, $\mathrm{P}=$ Petali, $\mathrm{K}=$ Kea, $\mathrm{E}=$ Evoia, $\mathrm{PB}=$ Cape Paximadi, $\mathrm{St}=$ Stira, $\mathrm{Ka}=$ Kavaliani Locations of STPs: Ky=Kynosoura, $\mathrm{Ve}=$ Velani, $\mathrm{Ch}=$ Chamolia, $\mathrm{Vr}=$ Vrisaki

Figure 2. Computational grid of HYMOD (depths in m)

strong inflow currents. These currents enter in the Gulf through the eastern wide opening (between the islands of Evoia and Kea) and leave the calculation domain mainly through the wide southern opening (between the islands of Kea and Makronisos). Tidal circulation is very weak, occurring mainly in the northern narrow strait. This observation has been verified with computations using a tidal boundary condition at the very narrow northern strait (12 hours period, amplitude $=9 \mathrm{~cm}$ ), which produced a flow field with very low flow velocities $(1-2 \mathrm{~cm} / \mathrm{sec})$. In winter and spring the flow is homogenous. In summer and autumn the flow field is stratified and is characterised by a strong thermocline, which is developed at depths ranging from 20 to $50 \mathrm{~m}$, with an

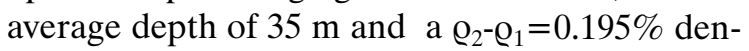
sity difference between the two layers.

Using this information and the velocity data obtained by the NCMR (1997) the following boundary conditions have been applied in the calculations: (i) The very narrow northern opening has been approximated as a closed boundary. (ii) The part of the eastern boundary, where inflow has been observed (north of Kea, see Figs 3 and 4), has been approximated as an inlet boundary with prescribed non-uniform (horizontal and vertical) velocity profiles and the remaining part has been approximated as an open sea boundary. (iii) The southern openings have been treated as outlet boundaries with a uniform vertical velocity profile, assuming that the outlet flow is equal to the flow, which enters through the eastern boundary. This simplified, but realistic treatment of the boundaries, which has been applied in both homogeneous and stratified (in both layers) flow field calculations, avoids the use of multi grids, do not present any computational problems (e.g. 
Table 6. Values of the coefficients of HYMOD.

\begin{tabular}{|lll|}
\hline Coefficient (Units) & Value determined in the calibration & Values in the literature \\
\hline $\mathrm{C}_{\mathrm{S}}$ & $10^{-5}$ & $1-3 \times 10^{-6}$ \\
\hline $\mathrm{C}_{\mathrm{i}}$ & 0.001 & $0.0001-0.05$ \\
\hline $\mathrm{C}_{\mathrm{b}}$ & 0.01 & $0.001-0.5$ \\
\hline $\mathrm{v}_{\mathrm{h}}$ & 100 & $10-1000$ \\
\hline
\end{tabular}

Table 7. Comparison of predicted and field values for chlorophyl-a

\begin{tabular}{|lllll|}
\hline Period & March 1996 & March 1996 & September 1996 & September 1996 \\
\hline Coastal region & Field values & Predicted values & Field values & Predicted values \\
\hline Lavrio & 0.35 & 0.31 & 0.32 & 0.32 \\
\hline $\begin{array}{l}\text { Keratea } \\
\begin{array}{l}\text { Rafina } \\
\text { Markopoulo }\end{array}\end{array}$ & 0.35 & 0.33 & 0.35 & 0.23 \\
\hline Marathonas & 0.45 & 0.45 & 0.44 & 0.44 \\
\hline
\end{tabular}

convergence) and produces flow fields, which are similar to the observed ones (NCMR, 1997).

Numerical grid and boundary conditions of QUMOD. The numerical grid used in the calculations is shown in Fig.1. Two series of data (NCMR, 1997) have been used in the callibration process; the first one (March 1996) for homogenous conditions and the second (September 1996) for stratified conditions. Under homogeneous conditions a single layer with 93 cells has been used. Under stratified conditions, two layers have been used; a surface layer ( $35 \mathrm{~m}$ in depth) and a bottom layer, comprised of 93 and 82 cells, respectively. The flow velocities were determined by HYMOD and were adapted to the coarser grid employed by the QUMOD. During this adaptation it was assumed that mass exchange between the surface and bottom layers due to convection and dispersion was negligible. The value of the dispersion coefficient was assumed to be constant throughout the simulated area, with a value of $\mathrm{E}=7.5 \mathrm{~m}^{2} / \mathrm{sec}$, obtained by callibration. Using the field data (NCMR, 1997), the following values of the concentrations at the open sea boundaries (external concentrations) have been used in both layers (the values in parentheses correspond to startified conditions): $\mathrm{A}=0.50(0.27) \mu \mathrm{g} / \mathrm{l}, \mathrm{OP}=0$ (0) $\mu \mathrm{g} / \mathrm{l}, \mathrm{IP}=1.30(1.80) \mu \mathrm{g} / \mathrm{l}, \mathrm{AM}=11.8$ (12.0) $\mu \mathrm{g} / \mathrm{l}, \mathrm{NO}=0.4(0.3) \mu \mathrm{g} / \mathrm{l}, \mathrm{BOD}=0.63(0.40) \mathrm{mg} / \mathrm{l}$ and $\mathrm{DO}=\mathrm{DO}_{\mathrm{S}}$.

3.2 Calibration of the model

Calibration of HYMOD. HYMOD has been calibrated for both the homogeneous and the stratified conditions against measurements (NCMR, 1997). The model showed a satisfactory agreement between the model predictions and the field data (Stamou and Pipilis, 1998). The values of the main coefficients of the model, which were determined in the calibration process (Stamou and Pipilis, 1998) are shown in Table 6, together with values commonly encountered in the literature. Generally, the values of the coefficients of the model are within the range of values reported in the literature, with the exemption of $C_{S}$.

A sensitivity analysis has also been performed (Stamou and Pipilis, 1998), which showed that the flow pattern is generally independent of the values of these coefficients, within the ranges of values reported in the literature. However, the magnitudes of the velocities are sensitive to the values of $\mathrm{C}_{\mathrm{S}}$ and $v_{\mathrm{h}}$, and increase with increasing $\mathrm{C}_{\mathrm{S}}$ values and decreasing $v_{h}$ values. There are not any noticeable changes in the calculations by changing the values of $C_{i}$ and $C_{b}$.

Calibration of QUMOD. For the values of the parameters shown in Table 4, a satisfactory agreement was observed between calculated and field values for all water quality variables, in both homogeneous and stratified conditions. Indicatively, in Table 7 ranges of predicted daily average concentration values of the surface layer for chlorophyll-a are compared with average field values, in the coastal regions of interest (see Fig.1). A similar agreement was noted for the 

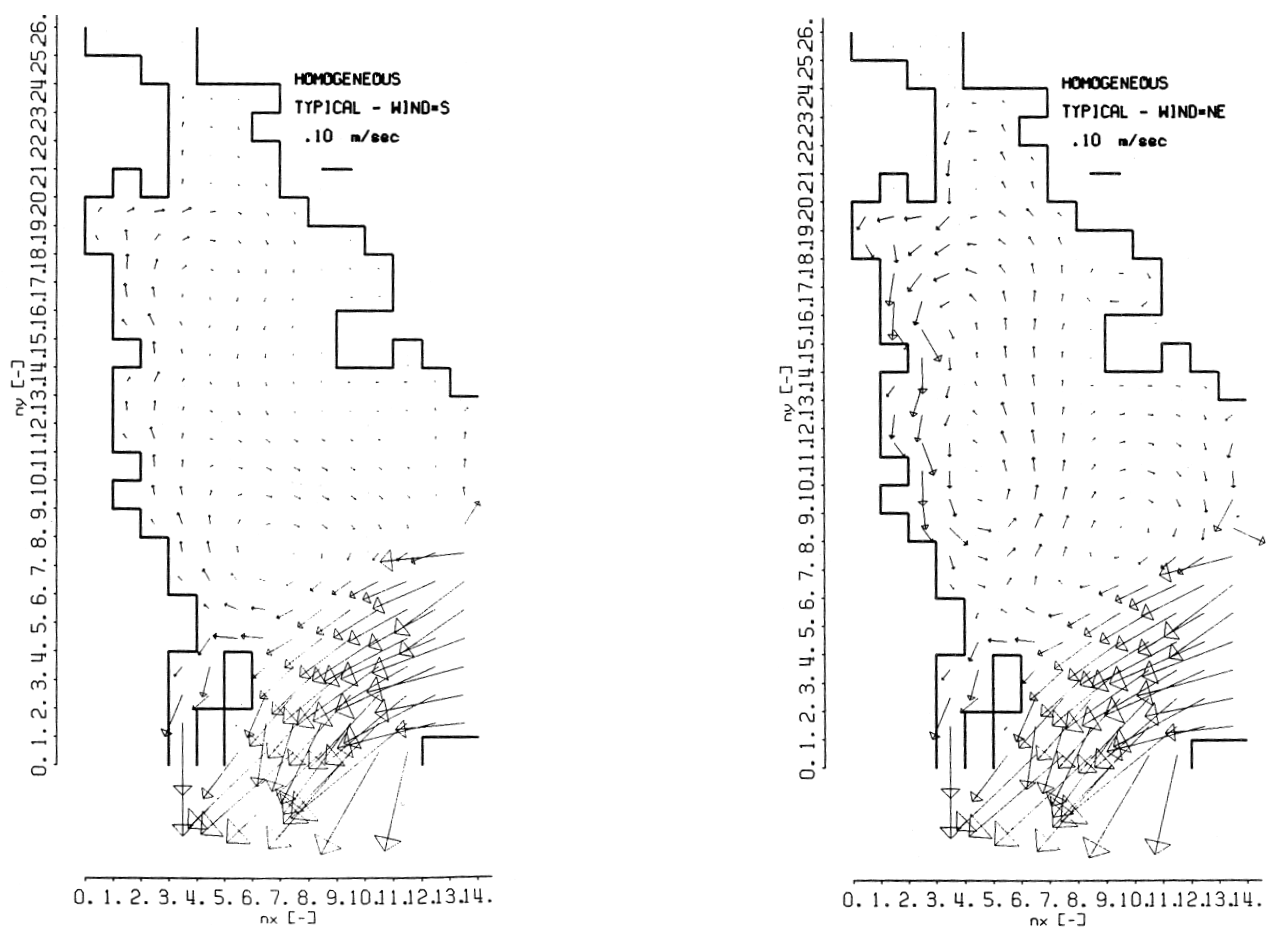

Figure 3. Calculated typical flow fields for the homogenous conditions

other water quality parameters.

\subsection{Application of the model}

Typical flow patterns. After the calibration of the model, the model has been applied to determine typical steady-state flow patterns for both the homogeneous and the stratified conditions. These flow fields are used as input to the water quality model. The typical flow fields have been calculated for the prevailing winds and the observed density difference. For the homogeneous conditions, the prevailing directions of winds are the $\mathrm{NE}$ and $\mathrm{S}$ with wind velocities equal to $\left(\mathrm{u}_{10}=-2.0 \mathrm{~m} / \mathrm{sec}, \mathrm{v}_{10}=-4.0 \mathrm{~m} / \mathrm{sec}\right)$ and $\left(\mathrm{u}_{10}=0.0 \mathrm{~m} / \mathrm{sec}, \mathrm{v}_{10}=+2.5 \mathrm{~m} / \mathrm{sec}\right)$, respectively. For the stratified conditions, the prevailing directions of winds are the NE and $\mathrm{S}$ with wind velocities equal to $\left(\mathrm{u}_{10}=-2.5 \mathrm{~m} / \mathrm{sec}, \mathrm{v}_{10}=-4.5 \mathrm{~m} / \mathrm{sec}\right)$ and $\left(\mathrm{u}_{10}=0.0 \mathrm{~m} / \mathrm{sec}, \mathrm{v}_{10}=+2.5 \mathrm{~m} / \mathrm{sec}\right)$, respectively. The typical flow patterns for both the homogeneous and the stratified conditions, are shown in Figs. 3 and 4, respectively.

The most important feature of the homogeneous flow is the strong incoming current (with average velocities in the range of $20-30 \mathrm{~cm} / \mathrm{sec}$ ), which enters through the eastern opening and exits through the two southern openings. The reproduction of this very important (not wind driven) characteristic in the calculations is due to the imposed boundary conditions. In the coastal zone of Attica, the flow is mainly wind driven, following the direction of the wind with velocities ranging from 3 to 15 $\mathrm{cm} / \mathrm{sec}$. In the case of the NE wind the flow is directed towards the south, forming two recirculation regions in the region between the flow along the coastal zone of Attica and the strong western current; a large anticlockwise recirculation region in the central area and a smaller clockwise recirculation region. For the $\mathrm{S}$ wind, the flow in the coastal zone is directed northwards, the large recirculation region becomes larger and changes to clockwise, while the smaller recirculation region becomes anti-clockwise and moves towards the northern part of the eastern boundary. The flow in the SW region between Attica and the island of Makronisos seems to be independent of the direction of the wind and is always directed southwards, forced by the open-sea boundary conditions, with velocities of the order of $10-15 \mathrm{~cm} / \mathrm{sec}$.

In the case of the stratified flow, velocity profiles are defined in the eastern strait as boundary conditions for both layers. As shown in Fig. 4, these boundary conditions produce an inflow with a NW direction. This inflow, which is significantly smaller than the inflow under homogeneous flow conditions, creates a anti-clockwise large recirculation region in both layers of the central area, 

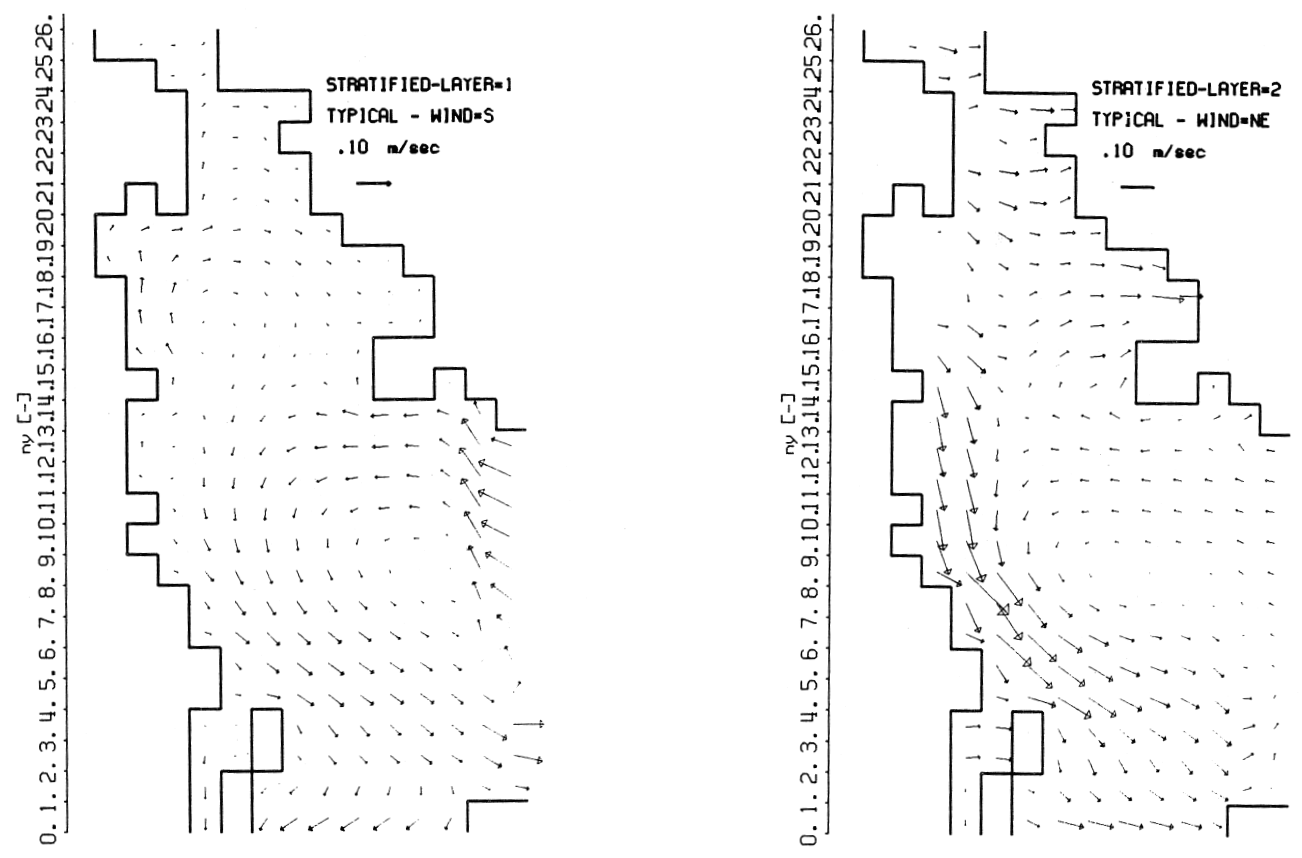

0.1.2.3.4.5.6.7.8.9.10.11.12.13.14.

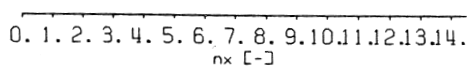
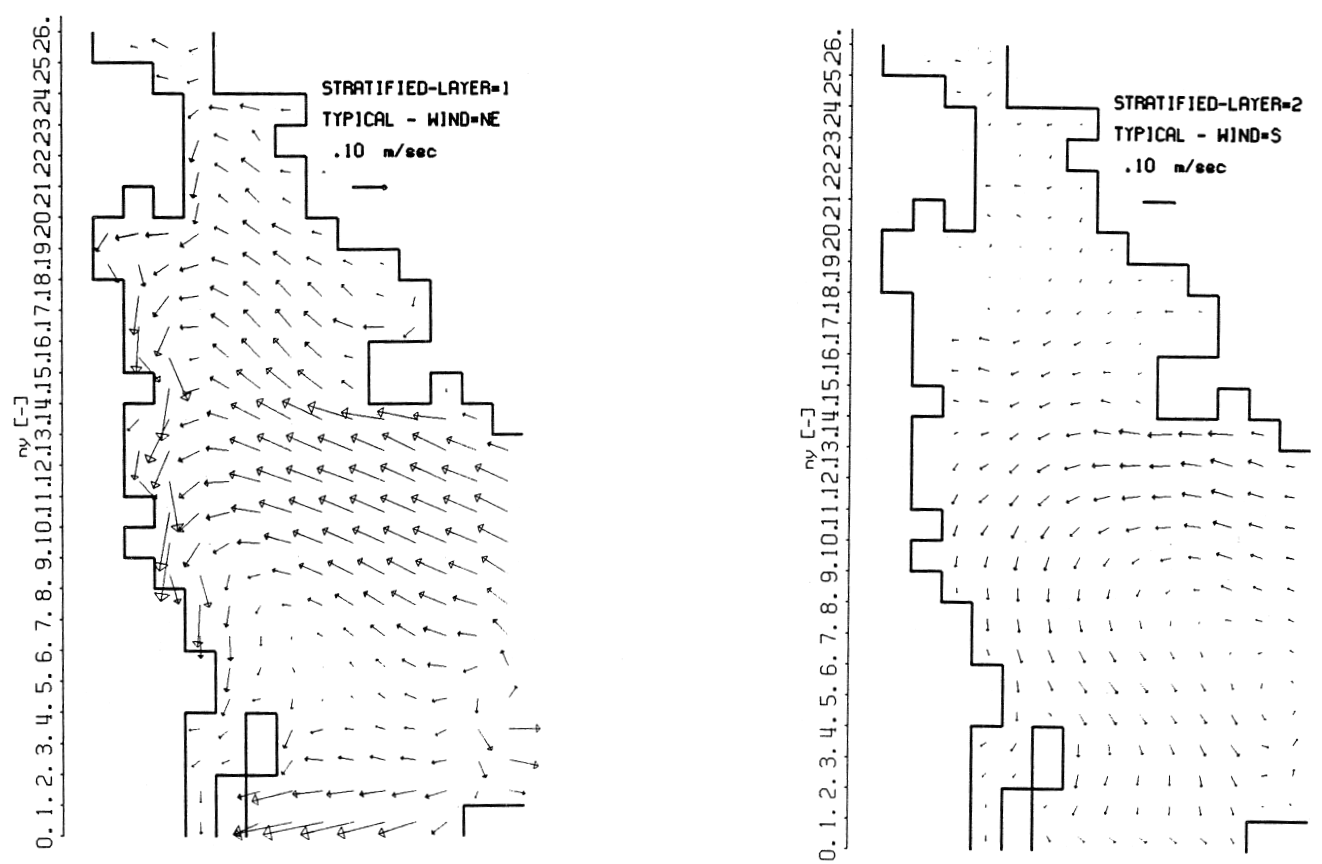

0.1.2.3.4.5.6.7.8.9.10.11.12.13.14.

Figure 4. Calculated typical flow fields for the stratified conditions (a) Top layer and (b) Bottom layer 
Table 8. Predicted values for Chlorophyl-a, DO and SD for various treatment options

\begin{tabular}{|cccccccc|}
\hline Area & & Scenario 1 & Scenario 1 & Scenario 2 & Scenario 2 & Scenario 3 & Scenario 3 \\
\hline & Layer & Surface & Bottom & Surface & Bottom & Surface & Bottom \\
\hline Coastal & A & $0.97-1.76$ & $0.39-0.49$ & $0.81-1.16$ & $0.38-0.47$ & $0.78-1.06$ & $0.37-0.42$ \\
\hline Coastal & SD & $9.7-13.3$ & & $12.2-14.3$ & & $12.7-14.6$ & \\
\hline Coastal & DO & $6.60-6.76$ & $6.48-6.53$ & $6.56-6.68$ & $6.48-6.53$ & $6.55-6.67$ & $6.48-6.53$ \\
\hline Outer Gulf & A & 0.57 & 0.46 & 0.56 & 0.46 & 0.55 & 0.46 \\
\hline Outer Gulf & SD & 16.35 & & 16.42 & & 16.48 & 6.77 \\
\hline Outer Gulf & DO & 6.46 & 6.77 & 6.46 & 6.77 & 6.46 & 6 \\
\hline
\end{tabular}

which is independent of the direction of the wind (see Fig.4). In the coastal zone of Attica, northwards of Porto Rafti, the flow of the top layer is mainly wind driven, as in the case of the homogeneous flow, following the direction of the wind with velocities ranging from 3 to $15 \mathrm{~cm} / \mathrm{sec}$. In the bottom layer the flow is performed towards the south. The same direction of flow is observed in both layers in the coastal region southwards of Porto Rafti, because the flow is mainly affected by the large recirculation region and is generally independent of the direction of the wind. In the case of the SE wind a smaller recirculation region is formed in the northern part of the area.

Water quality. Water quality calculations have been performed for the typical flow conditions and the 3 treatment scenarios. The discussion of the results focuses on the most important water quality variables, i.e. Chlorophyl-a, DO and Secchi disk (SD), with their predicted values for the 3 treatment scenarios shown in Table 8.

From the calculations and the figures of Table 8, the following conclusions are drawn:

(1) For all scenarios, the DO concentrations remain high and very close to saturation values.

(2) Biological treatment only (Scenario 1) results in Chlorophyll-a maximum concentrations of the surface layer equal to $0.97-1.76 \mu \mathrm{g} / \mathrm{l}$ for the coastal areas and $0.57 \mu \mathrm{g} / \mathrm{l}$ for the Outer Gulf. The respective minimum transparencies (SD) are in the range $9.70-13.30 \mathrm{~m}$ for the coastal areas and $16.35 \mathrm{~m}$ for the Outer Gulf.

(3) Biological treatment with $\mathrm{N}$ removal (Scenario 2, see also Fig. 1) results in lower Chlorophyll-a concentrations (as shown in Fig. 1). The mean values were reduced by $16.5-41.0 \%$ for the coastal areas, while for the Outer Gulf the differences were insignificant. The resulted minimum transparencies ranged between 12.20 and $14.30 \mathrm{~m}$.

(4) Biological treatment with $\mathrm{N}$ and P removal (Scenario 3) results in further reduction of the mean Chlorophyll-a concentrations to the order of 5-7 \% for the coastal areas, whereas no difference occurred for the Outer Gulf. The respective minimum transparencies ranged between 12.70$14.60 \mathrm{~m}$.

Therefore, it can be concluded that nitrogen is the limiting nutrient and its removal results in an improvement of the quality of the recipient, whereas the additional implementation of phosphorus removal has a rather limited impact.

\section{REFERENCES}

Kowalik Z., and Murty T.S., Numerical Modelling of Ocean Dynamics, Advanced Series of Ocean Engineering - 5, World Scientific, 1993.

National Center for Marine Research, Investigation of the Marine Ecosysytem of E-SE Attica from Marathonas to Anavissos, Final Report, Athens, 1997.

Noutsopoulos C., Gavalaki E. and Andreadakis A.: Evaluation of the Impact from the Discharge of Treated Sewage to the South East Saronikos Gulf Through Mathematical Water Quality Modelling, Wat. Sci. Tech (in print), 1999.

Stamou A. I., Christodoulou G. C., Bensasson L. A. and Lazaridis I. E., A Comparison of Models for Coastal Circulatio", Black Sea Regional Conference on Environment Protection Technologies for Coastal Areas, Wat. Sci. Tech., 32, No.7, pp.55-70, 1995.

Stamou A.I. and Pipilis K.G., Calibration and Application of a Hydrodynamic Model of Southern Evoikos Gulf" (submitted for publication to the Scientific Journal of the Technical Chamber of Greece), 1999. 